\title{
PERSPEKTIF HUKUM DAN HAK ASASI MANUSIA TERHADAP ANAK YANG MENJADI KORBAN PERDAGANGAN MANUSIA
}

\author{
Abu Hasin \\ Kantor Advokat Kabupaten Situbondo \\ Email : abuhasin175@gmail.com
}

\begin{abstract}
Abstrak
Perspektif yuridis terhadap anak yang menjadi korban kejahatan perdagangan manusia sudah banyak norma yuridis yang dibuat negara yang secara fundamental mengaturnya, bahwa tindak pidana atau kejahatan memperdagangkan anak sudah jelas-jelas sebagai perbuatan yang berbentuk melanggar norma hukum pidana. Dalam perspektif hak asasi manusia (HAM) terhadap anak yang menjadi korban kejahatan perdagangan manusia adalah berkaitan dengan masalah hak-hak anak, baik yang diatur dalam instrumen HAM internasional seperti UDHR, Kovenan Hak Anak, hingga produk yuridis Indonesia.
\end{abstract}

Kata kunci: anak, hak asasi manusia, hukum, korban

\begin{abstract}
Juridical perspective on children who are victims of human trafficking crimes has many juridical norms made by the state that fundamentally regulate them, that criminal acts or the crime of trafficking in children are clearly acts that violate criminal law norms. In the perspective of human rights (HAM) against children who are victims of human trafficking crimes is related to the issue of children's rights, both regulated in international human rights instruments such as the UDHR, the Covenant on Childrens Rights, to Indonesian juridical products.
\end{abstract}

Keywords: children, human rights, law,

\section{PENDAHULUAN}

Ada pernyataan Franklin D. Roosevelt, ${ }^{1}$ yang berbunyi "we cannot always build the future for our youth, but we can build our youth for the future." yang artinya kita tidak bisa selalu membangun masa depan untuk generasi muda kita, tetapi kita dapat membangun generasi muda kita untuk masa depan

Berdasarkan pernyataan Roosevelt itu dapat dijadikan peringatan bagi kita, bahwa membimbing atau membentuk atau melindungi generasi muda (anak) harus terus dilakukan dengan kesungguhan, bukan dengan sekedarnya. Para anak bangsa ini dituntutnya untuk menjadi sumberdaya strategis yang berguna bagi masa depan. Masalahnya, bagaimanakah membentuk anak hebat (berkualitas) di tengah perkembangan zaman atau perubahan yang sarat tantangan, yang diantaranya berpotensi menghancurkan seperti yang menimpa anak sekarang ini. Hal ini berarti menuntut anak butuh perlindungan.

\footnotetext{
${ }^{1}$ Ghaffar Hasyim, Negara dan Generasi Emas, Pimpres, Jakarta, 2015, hal. 23.
} 


\section{Jurnal Negara dan $\mathcal{X}$ eadilan \\ p-ISSN 2302-7010 e-ISSN 2721-9801}

Perlindungan anak bertujuan untuk menjamin terpenuhinya hak-hak anak agar dapat hidup, tumbuh, berkembang, dan berpartisipasi secara optimal sesuai dengan harkat dan martabat kemanusiaan, serta mendapat perlindungan dari kekerasan dan diskriminasi, demi terwujudnya anak Indonesia yang berkualitas, berakhlak mulia, dan sejahtera. Beberapa ketentuan yang diatur secara umum dalam Undang-Undang ini antara lain prinsip-prinsip dasar sesuai dengan Konvensi Hak-Hak Anak, Hak dan Kewajiban Anak, Kewajiban dan Tanggung Jawab Negara dan Pemerintah, Kewajiban dan Tanggung Jawab Masyarakat, Kewajiban dan Tanggung Jawab Keluarga dan Orang Tua, Kedudukan Anak, Pengasuhan dan pengangkatan anak, Penyelenggaraan perlindungan anak, Komisi Perlindungan Anak Indonesia.

Berkaitan dengan masalah pekerja anak, pemerintah Indonesia sudah meratifikasi Konvensi tentang Pengakhiran Bentuk Bentuk Terburuk Pekerja Anak melalui Undang-Undang Nomor 1 Tahun 2000 tentang Pengesahan ILO Convention No. 182 Concerning The Prohibition and Immediate Action for Elimination of The Worst Forms of Child Labour (Konvensi ILO Nomor 182 Mengenai Pelarangan dan Tindakan Segera Penghapusan Bentuk-bentuk Pekerjaan Terburuk untuk Anak). bentuk-bentuk pekerjaan terburuk yang berhubungan dengan pola memperdagangkan anak yang mengandung sejumlah pengertian :

1. segala bentuk perbudakan atau praktik-praktik sejenis perbudakan, seperti penjualan dan perdagangan anak-anak, kerja ijon (debt bondage) dan perhambaan serta kerja paksa atau wajib kerja, termasuk pengerahan anakanak secara paksa atau wajib untuk dimanfaatkan dalam konflik bersenjata;

2. pemanfaatan, penyediaan atau penawaran anak untuk pelacuran, untuk produksi pornografi, atau untuk pertunjukan-pertunjukan porno;

3. pemanfaatan, penyediaan atau penawaran anak untuk kegiatan haram, khususnya untuk produksi dan perdagangan obat-obatan sebagaimana diatur dalam perjanjian internasional yang relevan;

4. pekerjaan yang sifatnya atau lingkungan tempat pekerjaan itu dilakukan dapat membahayakan kesehatan, atau moral anak-anak.

Selain itu, Indonesia juga sudah meratifikasi konvensi mengenai usia minimum anak diperbolehkan bekerja, Undang-Undang Nomor 20 Tahun 1999 tentang Pengesahan ILO Convention No. 138 Concerning Minimum Age for Admission to Employment (Konvensi ILO Mengenai Usia Minimum untuk Diperbolehkan Bekerja). Sebelumnya, dalam Konvensi No. 5 Tahun 1919 mengenai Usia Minimum untuk sektor Industri, Konvensi No. 7 Tahun 1920 mengenai Usia Minimum untuk Sektor Kelautan, Konvensi No. 10 Tahun 1921 mengenai Usia Minimum untuk Sektor Agraria, dan Konvensi No. 33 Tahun 1932 mengenai Usia Minimum untuk Sektor Non Industri, menetapkan bahwa usia minimum untuk bekerja 14 (empat belas) tahun. Selanjutnya Konvensi No. 58 Tahun 1936 mengenai Usia Minimum untuk Kelautan, Konvensi No. 59 Tahun 1937 mengenai Usia Minimum untuk Sektor Industri, Konvensi No. 60 Tahun 1937 mengenai Usia Minimum untuk Sektor Non Industri, dan Konvensi No. 112 Tahun 1959 mengenai Usia Minimum untuk Pelaut, mengubah usia minimum untuk bekerja menjadi 15 (lima belas) tahun. Dalam penerapan berbagai Konvensi tersebut di atas di banyak negara masih ditemukan berbagai bentuk penyimpangan 


\section{Zurnal Negara dan $\mathcal{X}$ eadilan \\ p-ISSN 2302-7010 e-ISSN 2721-9801}

batas usia minimum untuk bekerja. Oleh karena itu ILO merasa perlu menyusun dan mengesahkan konvensi yang secara khusus mempertegas batas usia minimum untuk diperbolehkan bekerja yang berlaku di semua sektor yaitu 15 (lima belas) tahun.

Selain hal itu, dalam dasar pertimbangan Undang-Undang Republik Indonesianomor 35 Tahun 2014 Tentang Perubahan Atas Undang-Undang Nomor 23 Tahun 2002 Tentang Perlindungan Anak disebutkan, ${ }^{2}$ bahwa setiap anak berhak atas kelangsungan hidup, tumbuh dan berkembang serta berhak atas perlindungan dari kekerasan dan diskriminasi sebagaimana diamanatkan dalam Undang-Undang Dasar Negara Republik Indonesia Tahun 1945.

Norma yuridis itu jelas secara khusus mengatur perlindungan anak. Sedangkan secara umum disebutkan dalam Undang-Undang Republik Indonesia Nomor 21 Tahun 2007 Tentang Pemberantasan Tindak Pidana Perdagangan Orang, bahwa perdagangan orang, khususnya perempuan dan anak, merupakan tindakan yang bertentangan dengan harkat dan martabat manusia dan melanggar hak asasi manusia, sehingga harus diberantas. ${ }^{3}$

Meski secara yuridis diatur seperti itu, tapi dunia ini, khususnya di Indonesia, perdagangan orang tetap memprihatinkan. Perkembangan kejahatan semakin mengkhawatirkan, khususnya kejahatan yang menempatkan anak sebagai korbannya. Kondisi anak Indonesia bukannya bisa menikmati hak keamanan dan keselamatannya, tetapi justru semakin rentan. Menurut Aris Merdeka Sirait, bahwa Indonesia merupakan pemasok perdagangan anak dan wanita (trafficking) terbesar di Asia Tenggara. Berdasarkan penelitian menunjukkan, terdapat sekitar 200 sampai 300 ribu Pekerja Seks Komersil (PSK) berusia dibawah usia 18 tahun. Tidaak Cuma di dalam negeri, mereka juga memasok kebutuhan di Asia Tenggara. Data-data itu diungkapkan Sirait kepada wartawan pada suatu konferensi pers pemberantasan perdagangan perempuan dan anak di Jakarta. ${ }^{4}$

Sekitar 23 persen dari 6750 tenaga kerja wanita (TKW) yang bekerja di Hongkong ternyata bekerja di wilayah prostitusi. Diduga, beberapa perusahaan tenaga kerja telah menipu para pekerja itu. Tingginya angka trafficking itu karena pemerintah kurang sigap dalam menangganinya. Tenaga Kerja Indonesia (TKI) di luar negeri misalnya banyak yang masih dibawah umur. Mereka biasanya tidak mempunyai surat kenal lahir, dalam pembuatan paspor mereka memalsukan usianya. Masa pihak imigrasi tidak bisa menilai umur mereka berdasarkan wajahnya. Masalah perdagangan perempuan dan anak sampai saat ini belum menjadi perhatian pemerintah secara serius. Ketidakseriusan pemerintah menangani masalah perdagangan perempuan dan anak terlihat dari tidak tegasnya sikap pemerintah dalam melihat masalah perdagangan perempuan dan anak. Sirait juga mengungkapkan bahwa di Indonesia terdapat 75 ribu titik PSK, baik legal ataupun illegal. ${ }^{5}$

${ }^{2}$ Undang-Undang Republik Indonesianomor 35 Tahun 2014 Tentang Perubahan Atas Undang-Undang Nomor 23 Tahun 2002 Tentang Perlindungan Anak

${ }^{3}$ Undang-Undang Republik Indonesia Nomor 21 Tahun 2007 Tentang Pemberantasan

Tindak Pidana Perdagangan Orang

${ }^{4}$ Hikmawati, Anak-anak Inonesia di Simpang Jalan, LPAI, Jakarta, 2011, hal. 2.

5 Ibid. 


\section{$\mathcal{H}$ urnal Negara dan Keadilan \\ p-ISSN 2302-7010 e-ISSN 2721-9801}

Sirait mengemukakan bahwa untuk mengatasi masalah prostitusi tidak cukup hanya dengan undang-undang, tetapi diperlukan alokasi dana yang seimbang untuk melakukan pemberantasan perdaganagan tersebut. Menurut data yang didapatkan dari PBB prostitusi memberikan keuntungan sekitar U\$ 7 miliar, sehingga kita harus mengimbanginya dengan dana yang cukup untuk melakukan program preventif dan rehabilitasi. ${ }^{6}$

\section{METODE PENELITIAN}

Setiap penelitian ada jenis, kategro, dan pendekatannya. Oleh karean iau, sebagaimana uraian dari permasalahan dan tujuan dari penulisan karya ilmiah ini, penulis menggunakan jenis penelitian bersifat yuridis normatif, yang dalam penelitian ini dimaksudkan untuk memberikan data tentang norma-norma hukum yang seteliti mungkin yang mengatur tentang perilaku manusia atau keadaan yang ditimbulkannya. Adapun pendekatan yang digunakan dalam penelitian ini adalah pendekatan perundang-undangan dan konsepsional serta perbandingan.

Pada penelitian hukum yuridis normatif atau penelitian hukum kepustakaan, bahan pustaka merupakan data dasar yang dalam (ilmu) penelitian digolongkan sebagai data sekunder.

Dalam penelitian ini, teknik content analisis yang digunakan secara deskriptif, artinya dengan menggunakan teknik analisa data deskriptif diharapkan dapat memperoleh paparan informasi tentang suatu gejala, peristiwa, kejadian sebagaimana adanya.

\section{PEMBAHASAN}

Di zaman sekarang ini kasus perdagangan manusia atau dikenal dengan "trafficking", terutama terhadap anak dan perempuan, tergolong jenis perbudakan pada era modern. Setiap tahun diperkirakan ada delapan hingga sembilan ratus ribu orang diperdagangkan melintasi batas internasional ke dalam kondisi kerja paksa atau mirip perbudakan di zaman purba. Meskipun angka yang pasti sulit diperoleh, namun terdapat bukti kuat bahwa perdagangan perempuan, khususnya anak-anak merupakan fenomena yang serius dan kompleks sekali di masyarakat.

Sebagai contoh yang terjadi di Sumatera Utara sepanjang tahun 2008, kasus-kasus kekerasan terhadap anak memang cukup tinggi. Data PKPA menyebutkan, terhitang Januari-November 2008 tercatat 373 kasus kekerasan terhadap anak, meningkat dari tahun sebelumnya 308 terhitung Januari-November 2007. PKPA menangani 130 kasus kekerasan pada anak tahun 2008. Sementara data KKSP menyebutkan, 62 kasus kekerasan terhadap anak sepanjang 2008. Sedangkan Pusaka mencatat 239 kasus kekerasan terhadap anak. ${ }^{7}$

Direktur Eksekutif KKSP, Muhammad Jailani. Menyebutkan, bahwa Sumut masih cenderung mengabaikan masalah anak-anak yang menjadi korban kekerasan di sekolah. Anak-anak korban kekerasan di sekolah, anak-anak korban kekerasan seksual, anak-anak korban traffiking dan anak-anak yang berkonflik dengan hukum merupakan kelompok yang paling menderita lemahnya perlindungan hukum ini. ${ }^{8}$

\footnotetext{
${ }^{6}$ Ibid, hal. 3.

${ }^{7}$ http://www.kksp.or.id/id/cetak.php?id=223, diakses tanggal 4 Mei 2019.

${ }^{8}$ Ibid
} 


\section{Hurnal Negara dan $\mathcal{X}$ eadilan \\ p-ISSN 2302-7010 e-ISSN 2721-9801}

Hukum dibuat untuk mengatur tingkah laku manusia (seseorang), agar mengetahui hak dan kewajibannya dalam hidup bermasyarakat menurut hukum. Dengan diatur oleh hukum, seseorang tahu perbuatan-perbuatan apa yang boleh dan tidak boleh dilakukan, mengetahui hak dan kewajibannya menurut hukum, dengan tujuan supaya hak seseorang tidak dilanggar dan berbenturan dengan hak orang lain. ${ }^{9}$

Apabila seseorang melanggar hak orang lain akibatnya akan terjadi pelanggaran hak yang merugikan hak atau kepentingan sesame manusia. Apabila terjadi pelanggaran hak, maka hidup masyarakat atau manusia menjadi kacau. Salah satu subyek masyarakat yang belum terpenuhi hak-haknya menurut hukum itu adalah anak-anak. Hak-hak mereka seringkali diabaikan dan dipermainkan oleh sistem maupun budaya yang berlaku di tengah masyarakat. Terbukti, tidak sedikit diantara anak-anak yang berusaha atau sedang berjuang memenuhi kebutuhan hidupnya yang menjadi korban penyiksaan, diskriminasi, atau perlakuan-perlakuan tidak manusiawi.

Perlakuan tidak manusiawi seperti kejahatan terhadap anak-anak, adalah bentuk lain dari perbuatan yang berlawanan atau bertentangan dengan hukum. Kejahatan terhadap anak-anak sedang marak-maraknya, yang membuat berbagai pihak berusaha memberikan jalan keluar untuk ikut menyelesaikannya.

Fenomena globalisasi yang merupakan proses pengintegrasian seluruh warga dunia secara ekonomi, sosial, budaya dan politik dalam seluruh tatanan yang dibangun dari masing-masing kolonialisme ikut mendorong tingginya angka buruh migran di Indonesia serta mempengaruhi migrasi warga Indonesia serta mempengaruhi arah migrasi warga Indonesia dalam mencari nafkah. Arah migrasi dari buruh migran Indonesia mengikuti pola yang sama, yaitu amenuju negara ekonomi kuat, seperti Saudi Arabia, Uni Emirat Arab di Timur Tengah (Asia Barat) dan Taiwan, Hongkong, Singapura dan Malaysia di Asia Timur. ${ }^{10}$

Perempuan di luar negeri yang tertipu pada ajakan agen trafficking atau perdagangan manusia profesional. Jaringan tersebut telah menyebar di regional kita, antarnegara, hingga lintas benua. Sebab, keuntungan dari perdagangan manusia merupakan salah satu di antara tiga sumber pendapatan teratas kejahatan terorganisasi setelah perdagangan narkotika dan senjata. ${ }^{11}$

Perbincangan tentang trafficking sebenarnya telah lama muncul ke permukaan. Dalam beberapa konferensi dan pertemuan antar kepala negara di forum internasional, telah dibahas komitmen dalam memberantas jaringan keji nan munkar itu.

Tidak ada negara yang kebal terhadap perdagangan manusia. Setiap tahun, diperkirakan 600.000-800.000 laki-laki, perempuan, dan anak-anak diperdagangkan menyeberangi perbatasan-perbatasan internasional (beberapa organisasi internasional dan organisasi swadaya masyarakat mengeluarkan angka yang jauh lebih tinggi).

Para korban dipaksa untuk bekerja di tempat pelacuran, tambang-tambang, dan tempat kerja buruh berupah rendah sebagai pelayan rumah, prajurit di bawah umur, dan berbagai bentuk perbudakan di luar kemauan mereka. Diperkirakan,

\footnotetext{
${ }^{9}$ Umar Said Sugiharto, Dinamika Hukum, Pebruari 2004, hal. 75.

${ }^{10}$ www.tempointeraktif.com, 15 September 2006, diakses tanggal 5 Agustus 2018.

${ }^{11}$ Nurlaily Nisyah, Jawapos, 13 April 2006, diakses 7 Agustus 2018.
} 


\section{$\mathcal{H}$ urnal Negara dan Keadilan \\ p-ISSN 2302-7010 e-ISSN 2721-9801}

lebih dari separo para korban yang diperdagangkan secara internasional diperjualbelikan untuk eksploitasi seksual. ${ }^{12}$

Masalah perdagangan manusia (human trafficking) adalah masalah yang telah mendunia. Hampir setiap negara mengalami masalah itu. Tak terkecuali Indonesia. Bahkan, di Amerika sendiri, kasus seperti itu mengantongi korban sekitar 14 ribu- 17 ribu orang. Dengan demikian, penanganan secara khusus amat diperlukan dalam pengentasan masalah trafficking tersebut.

Meski sudah agak lama, dilustrasikan, bahwa pada 2000, di seluruh dunia diperkirakan ada 700 ribu-2 juta perempuan dan anak-anak yang diselundupkan. Dari jumlah tersebut, 200 ribu- 225 ribu di antaranya terjadi di negara-negara Asia Tenggara. Namun, angka tersebut meningkat pada 2003. Laporan dari Bureau of Public Affairs, US Departemen of Sate, pada Juni 2003 memaparkan, tiap tahun 800 ribu-900 ribu manusia diselundupkan dengan mengabaikan batas-batas internasional. Penyelundupan itu ditujukan untuk memasok pasar perdagangan seks internasional dan buruh. ${ }^{13}$

Dalam kasus itu, lebih parahnya lagi, penyelundupan tersebut dilakukan melalui jejaring kejahatan internasional (transnational criminality) yang terorganisasi rapi, baik melalui jalur negara perantara maupun langsung. Entah berapa lagi yang akan menjadi korban mengingat modus operandi pekerjaan itu bersifat clandestin activities.

Sebagai bangsa beradab, jika kita menelaah lebih jauh, problem trafficking bukanlah permasalahan baru yang hadir begitu saja pada masa kini. Pada masa kolonial, hal itu telah terjadi. Migrasi tenaga kerja pada satu titik tertentu, misalnya. Penduduk lokal dipindahkan, baik secara paksa maupun sukarela melalui jalur perbudakan, perdagangan karena utang, atau pun perpindahan yang dilakukan negara dalam hal kriminal atau pengasingan politik ${ }^{14}$

Demikian itulah realita memprihatinkan dan memilukan dari kondisi kehidupan anak-anak di dunia sekarang. Untuk melindungi anak-anak yang merupakan generasi mendatang dunia, seluruh negara harus bersama-sama memikul tanggungjawab. Dengan demikian, kesulitan dan problema kehidupan anak-anak akan berhasil ditekan untuk kemudian melangkah ke arah realisasi hakhak mereka.

Badan dunia Organisasi Buruh Internasional (ILO) memperkirakan, di Indonesia terdapat 4.201.452 anak (berusia di bawah 18 tahun) terlibat dalam pekerjaan berbahaya, lebih dari 1,5 juta orang di antaranya anak perempuan. Bahkan, data IPEC/ILO memperkirakan, terdapat 2,6 juta pekerja rumah tangga (PRT) di Indonesia dan sedikitnya 34,83 persen tergolong anak. Sekitar 93 persen anak perempuan (Kompas, 2/7/05: 4). PRT anak perempuan berada dalam posisi rentan, mulai situasi kerja buruk, eksploitasi, hingga kekerasan seksual. Di pedesaan, kemiskinan, pernikahan dini, minimnya pendidikan, dan kondisi kesehatan yang buruk mendorong anak perempuan terjerembap dalam prostitusi dan masuk dalam jerat perdagangan manusia

Dalam kasus seperti itu, sebuah penilaian yang pernah dilontarkan Departemen Luar Negeri Amerika Serikat patut menjadi bahan renungan bagi kita. Pasalnya, mereka menilai pemerintah Indonesia cenderung membiarkan atau

\footnotetext{
${ }^{12}$ Ibid.

${ }^{13}$ Windo Wibowo, Jawa Pos, 14 April 2006, diakses 7 Agustus 2019.

${ }^{14}$ Ibid.
} 


\section{Zurnal Negara dan $\mathcal{X}$ eadilan \\ p-ISSN 2302-7010 e-ISSN 2721-9801}

mengabaikan perdagangan manusia (trafficking in person), baik untuk dijual tenaganya maupun buat eksploitasi seksual. ${ }^{15}$

Berdasarkan kenyataan itu, tidak mengherankan hal ini disorot dunia sebagaimana yang dilakukan oleh Amerika. Bisnis berlaba lumayan besar itu ternyata mampu menggemukkan devisa negara. Pada 1999-2001, penerimaan devisa dari sektor ini mencapai USD 3,1 miliar. Pada 2005, penerimaan meningkat, menjadi USD 5 miliar (sekitar Rp 45 triliun dengan kurs Rp 9 ribu).

Sangat ironis dengan menyebut, bahwa itu jumlah yang fantastis untuk sebuah penerimaan devisa negara. Memang, tidak ada yang salah pada niat untuk memperbesar devisa dari tenaga kerja Indonesia. Akan tetapi, yang menjadi pertanyaan, apakah manusia-manusia Indonesia akan terus menjadi komoditas? apakah anak-anak Indonesia akan terus menjadi obyek yang diperdagangkan?

Kenyataan memilukan lain yang tidak teelakkan, bahwa di antara sekian banyak kasus trafficking, perempuan selalu menjadi sasaran empuk. Memang, yang paling banyak di antara tenaga kerja Indonesia yang dikirim ke luar negeri sebagai pembantu rumah tangga adalah wanita. Ditambah lagi dengan penilaian sosok perempuan yang sering diidentikkan dengan sifat lemah lembut, tidak berdaya, dan selalu tergantung, telah menjadi stigma dan motivasi tersendiri bagi oknum penjual manusia.

Potret perempuan, idealnya, dilihat sebagai manusia dengan hak-hak yang sama dan perlu dilindungi. Kenyataannya, mereka justru sering dilihat sebagai objek yang setiap saat bisa "dimanfaatkan" untuk kepentingan orang-orang yang tidak berperikemanusiaan ${ }^{16}$

. Bangsa ini akan runtuh kalau kekerasan terhadap anak dibiarkan terus terjadi. Petuah tersebut dilontarkan praktisi Komisi Nasional Perlindungan Anak (Komnas PA) Seto Mulyadi. Nasihat indah Kak Seto itu tidak mampu menyentuh ceruk terdalam hati nurani kita. Terbukti, kasus-kasus kekerasan terhadap anak (child abuse) masih terus menghiasi pemberitaan media massa kita. Ironisnya, mayoritas kasus kekerasan terhadap anak terjadi di dalam rumah dan dilakukan kerabat-kerabat terdekat anak. Data nasional menunjukkan, sedikitnya 23,1 persen korban kekerasan dalam rumah tangga (KDRT) adalah anak-anak.

Selama tahun 2005, Komnas PA menemukan 866 kasus kekerasan terhadap anak yang terbagi atas 327 kasus perlakuan salah secara seksual, 233 kasus perlakuan salah secara fisik, 176 kasus kekerasan psikis, dan 130 kasus penelantaran (pembiaran) anak. Lebih menyedihkannya lagi, para pelaku kekerasan terhadap anak itu mayoritas adalah orang yang dikenal anak, yaitu 69 persen. Cobalah tengok beberapa kekerasan yang menimpa anak-anak bangsa. Di awal 2006, Eka Suryana (7) dibunuh di Jakarta Utara oleh ibu tirinya. Sementara itu, di Serpong, Tangerang, Indah Sari $(3,5)$ dan Lintang Syaputra (11 bulan) dibakar oleh ibunya. Tubuh keduanya disiram minyak tanah, kemudian disulut korek api hingga terbakar. Masih di Jakarta Utara, Siti Ihtiyatus Soleha (8) disetrika ayah kandungnya sendiri. Dia mengalami luka bakar di kedua kaki dan tangannya. Di beberapa daerah lain, ada berita orang tua terlibat penjualan anak ke lokasi pelacuran. Mereka (anak-anak) ini diserahkan ke calo-calo atau orangorang yang bisa memberikan imbalan uang. ${ }^{17}$

\footnotetext{
${ }^{15}$ Hadian Syah, Jawa Pos, 15 April 2006, akses 8 Agustus 2019.

16 Ibid.

${ }^{17}$ Eri Iriawan, Jawa Pos 16 April 2006, akses 8 Agustus 2019.
} 


\section{Jurnal Negara dan Zeadilan \\ p-ISSN 2302-7010 e-ISSN 2721-9801}

Rachmat Syafaat (2002) pernah menyebutkan, bahwa Pada tingkat dunia perdagangan perempuan terkait erat dengan kriminalitas transnasional dan hal ini dinyatakan sebagai pelanggaran Hak Asasi Manusia (HAM) berat. Sedangkan Negara Indonesia tergolong dalam TIER 3, yaitu Negara yang diasumsikan tidak serius menangani masalah perdagangan manusia "trafficking" khususnya perdagangan perempuan. Tidak memiliki perekat perundang-undangan yang dapat mencegah, melindungi dan menolong korban serta tidak memiliki prundangundangn untuk melakukan penghukuman terhadap pelaku perdagangan manusia. KUHP hanya memiliki satu pasal saja yaitu pasal 297 KUHP menyatakan bahwa "perdagangan perempuan (umur tidak disebutkan) dan perdagangan anak laki-laki yang belum cukup umur, diancam dengan pidana penjara raling lama enam tahun". Adalah mengatur secara eksplisit tentang perdagangan perempuan, namun ancaman pidananya masih terlalu ringan. Jelas hal ini sangat mengkhawatirkan dan harus segera ada langkah-langkah kongkret dari pemerintah untuk memiliki perangkat pencegahan, perlindungan dan pertolongan terhadap korban, serta penghukuman yang diperlukan untuk memberantas perdagangan manusia. ${ }^{18}$

Dengan kondisi semacam itu, berarti telah menempatkan Indonesia masuk dalam standar 111 yakni "kategori berbahaya", hal ini disampaikan Sri Rejeki Sumaryoto (saat menjabat oleh Menteri Negara Pemberdayaan Perempuan (Meneg PP). Dalam pidatonya di Semarang pada tanggal 14 April 2002, bahwa untuk menanggulangi masalah perdagangan perempuan, pemerintah Indonesia harus melakukan upaya, baik yang bersifat praktis maupun strategis. Upaya yang saat ini dipersiapkan pemerintah Indonesia adalah merancang sebuah rencana aksi nasional penanggulangan perdagangan perempuan serta RUU penanggulangan perdagangan perempuan di Indonesia. ${ }^{19}$

Kasus-kasus yang menyangkut perdagangan anak terus terjadi di masyarakat. Berbagai pemberitaan dan pendapat di atas menunjukkan, bahwa masalah yang dihadapi oleh anak Indonesia dewasa ini tidaklah ringan. Mereka (anak-anak), khususnya perempuan sedang menghadapi problem berat yang menimpanya dan menjadi ancaman serius bagi masa depannya. Jaringan kejahatan internasional terus menerus mencari sasaran di Indonesia yang memperlakukan anak-anak sebagai korbannya dengan tujuan diperdagangkan. Jaringan kejahatan internasional ini telah menjadikan anak-anak Indonesia sebagai obyeknya. Anakanak Indonesia telah menjadi bagian dari obyek sindikat perdagangan manusia (trafficking).

Kejahatan memperdagangkan manusia anak semakin memprihatinkan. Ahmad Sofian mengatakan, kejahatan seksual terhadap anak selalu mengintai di sekitar mereka. Sejauh ini, berdasarkan penanganan kasus yang dilakukan PKPA, acapkali korban kekerasan seksual tidak mendapatkan intervensi dalam pemulihan psikologisnya, bahkan sebaliknya justru stigma negatif dari masyarakat yang mereka terima. ${ }^{20}$

Perspektif yuridis (hukum) terhadap anak yang menjadi korban kejahatan perdagangan manusia sudah banyak norma yuridis yang dibuat negara yang secara

${ }^{18}$ Rachmat Syafaat, Perdagangan Manusia, UM Pres, Malang.2002, hal, 1-2.

${ }^{19}$ Kompas, 5 April 2002, akses 8 Agustus 2019.

${ }^{20}$ Abdul Manaf, Anak-anak dalam Hegemoni Kejahatan Mutakhir, K-Pres, Bandung, 2011, hal. 2. 


\section{Hurnal Negara dan $\mathcal{X}$ eadilan \\ p-ISSN 2302-7010 e-ISSN 2721-9801}

fundamental mengaturnya, bahwa tindak pidana atau kejahatan memperdagangkan anak sudah jelas-jelas sebagai perbuatan yang berbentuk melanggar norma hukum pidana. Negara berkewajiban menciptakan rasa aman dan memberikan perlindungan hukum kepada setiap anak Indonesia agar mereka tumbuh serta berkembang secara wajar dan berperan serta dalam pembangunan. Negara telah membuat atau membentuk peraturan perundang-undangan yaitu Kitab undang-undang Hukum Pidana (KUHP) maupun norma hukum pidana lain diluar KUHP seperti UU tentang Perlindungan Anak, Undang-undang tentang Hak Asasi Manusia, dan Undang-undang yang mengatur mengenai pemberantasan memperdagangkan orang yang kesemuanya itu memuat dan mengatur hal-hal tertentu mengenai jaminan perlindungan anak.

Dalam perspektif hak asasi manusia (HAM) terhadap anak yang menjadi korban kejahatan perdagangan manusia adalah berkaitan dengan masalah hak-hak anak, baik yang diatur dalam instrumen HAM internasional seperti UDHR, Kovenan Hak Anak, hingga produk yuridis Indonesia. Adapun hak-hak anak yang harus mendapatkan perhatian diantaranya adalahm mendapat bantuan-bantuan fisik (pertolongan pertama kesehatan, pakaian naungan dan sebagainya) ketika awal ditemukan, harus mendapat bantuan penyelesaian permasalahan (melapor, penasehat hukum dan pembelaan), mendapat kembali hak miliknya, mendapat pembinaan dan rehabilitasii, dan lain sebagainya.

\section{KESIMPULAN}

Perbandingan antara perspektif hukum dengan perspektif hak asasi manusia (HAM) terhadap anak yang menjadi korban perdagangan manusia, bahwa dari sisi kesamaan, kedua kajian ini sama-sma membahas soal anak yang menjadi korban perdagangan manusia, praktik perdagangan manusia atau dengan mengorbankan anak identic dengan tindakan keji dan sebagai pelanggaran norma, dan sama-sama juga berkedudukan sebagai bentuk pelecehan harkat dan martabat kemanusiaan. Sedangkan dari sudut perbedaannya, bahwa dalma perspektif HAM, lebih bersifat umum atau kajiannya lebih lebih menempatkan sisi kemanusiaan anak, sedangkan dari sisi yuridis, perdagangan manusia disebut secara tegas sebagai suatu pelanggaran HAM dan tindak pidana (kejahatan).

Buku

\section{DAFTAR PUSTAKA}

Abdul Manaf, Anak-anak dalam Hegemoni Kejahatan Mutakhir, K-Pres, Bandung, 2011.

Ghaffar Hasyim, Negara dan Generasi Emas, Pimpres, Jakarta, 2015, hal. 23.

Hikmawati, Anak-anak Inonesia di Simpang Jalan, LPAI, Jakarta, 2011

Rachmat Syafaat, Perdagangan Manusia, UM Pres, Malang.2002.

Jurnal

Umar Said Sugiharto, "Masaah Penegalan Hukum", Dinamika Hukum, Pebruari 2004.

\section{Peraturan Perundanag-undangan}

Undang-Undang Republik Indonesianomor 35 Tahun 2014 Tentang Perubahan Atas Undang-Undang Nomor 23 Tahun 2002 Tentang Perlindungan Anak 


\section{Jurnal Negara dan $\mathcal{X}$ eadilan \\ p-ISSN 2302-7010 e-ISSN 2721-9801}

Undang-Undang Republik Indonesia Nomor 21 Tahun 2007 Tentang Pemberantasan Tindak Pidana Perdagangan Orang

\section{Internet dan Koran}

Eri Iriawan, Jawa Pos 16 April 2006, akses 8 Agustus 2019.

Hadian Syah, Jawa Pos, 15 April 2006, akses 8 Agustus 2019.

http://www.kksp.or.id/id/cetak.php?id=223, diakses tanggal 4 Mei 2019.

Kompas, 5 April 2002, akses 8 Agustus 2019.

www.tempointeraktif.com, 15 September 2006, diakses tanggal 5 Agustus 2018.

Nurlaily Nisyah, Jawapos, 13 April 2006, diakses 7 Agustus 2018.

Windo Wibowo, Jawa Pos, 14 April 2006, diakses 7 Agustus 2019. 